Journal Home Page:

http://perlinguam.journals.ac.za

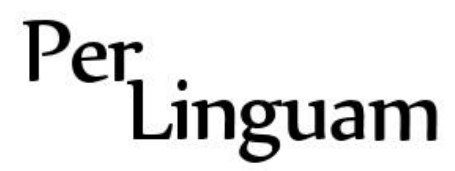

A Journal for Language Learning Tydskrif vir Taalaanleer

\title{
DEALING WITH BARRIERS TO THE INTEGRATION OF COMPUTER-ASSISTED LANGUAGE LEARNING IN AN AFRICAN LOW-TECH CONTEXT: IS THE TPACK FRAMEWORK ENOUGH? AN ANALYSIS OF ICT INTEGRATION IN A LOW-TECH CONTEXT
}

Joseph Blaise Ngandeu

University of Kwazulu-Natal

\begin{abstract}
The use of technology in teaching and learning in general, and in language teaching and learning in particular, is on the rise. Institutions of higher learning or teachers who adopt technology as a means to enhance teaching and learning are confronted with a number of challenges or barriers. Overcoming them has been a preoccupation for researchers. Effective integration of information and communication technology (ICT) requires a set of skills, and researchers have been proposing frameworks in order to conceptualise it. The technological pedagogical content knowledge (TPACK) framework appears to be the most coherent and practicable framework. A computer-assisted language learning (CALL) experience was carried out at the University of Buea. Through an explanatory research approach, this paper describes this CALL experience and shows that it follows the TPACK principles. Given the barriers that emerged during instantiation, the paper questions the sufficiency of the TPACK framework for a successful integration of ICT in an African context and argues that teachers who want to enhance their teaching with technology need more than technology, pedagogy and content knowledge - design thinking capacities as well as knowledge about how to pilot innovation are also necessary.
\end{abstract}

Keywords: barriers to ICT integration, TPACK, ICT integration, low-tech context, design thinking

\section{INTRODUCTION}

Given the rate at which the educational world has embraced information and communication technology (ICT), it is quite difficult to envisage a 21st-century classroom without it. Researchers (Lwoga, 2012; Rumanyika \& Galan, 2015; Ssekakubo, Suleman \& Marsden, 2011) have outlined the benefits of technology. Teachers or institutions of higher learning who choose technology as a means to enhance teaching and learning are faced with a number of challenges or barriers. Identifying and overcoming these barriers has been a preoccupation for researchers. The barriers that have been identified are either external or internal to the teacher. Many ICT integration models have been developed in order to overcome these barriers. They serve either as a framework for the integration process by describing the different steps to follow (Substitution, Augmentation, Modification, and Redefinition [SAMR] model) (Puentedura, 2006), as an 
indicator of the level of a state or an institution in the process of integration (continuum approach) (Unesco, 2002), or as a framework to describe the different types of knowledge necessary for a successful integration of ITC into education (the technological pedagogical content knowledge [TPACK] framework) (Mishra \& Koehler, 2006). This latter model is used in this paper to describe the integration of technology in a French as a foreign language class in a selected university in Cameroon. Because of the barriers that emerged in that computer-assisted language learning (CALL) experience, despite the set of TPACK skills characterising the teacher, the question of whether the TPACK knowledge is enough for ICT integration in a context like that of this university is posed. This paper argues that teachers who want to enhance their teaching with technology need more than technology, pedagogy and content knowledge. To that end, the paper first presents what literature describes as barriers to ICT integration, then the TPACK framework as theoretical considerations underpinning the work. The paper then proceeds to describe the context of the research where, in principle, the necessary conditions for technology integration are met. In line with the explanatory nature of this research, the paper further tests the TPACK framework by showing how it applies to a CALL project instantiated in the above-mentioned context, before pointing out its insufficiency through the analysis of emerging barriers.

\section{BARRIERS TO THE INTEGRATION OF ICT INTO EDUCATION}

Integrating ICT into education goes with a number of challenges. Research on this issue abounds, and the most common barriers identified by researchers are related to issues such as economy of teaching; transformation of teaching style (Poellhuber \& Bou-Langer, 2001); poor technical assistance and lack of funding for equipment (Angeli \& Valanides, 2005; Cox, Preston \& Cox, 1999; Cuban, 2001; Snoeyink \& Ertmer, 2001); lack of proper training and fear of change (Omar \& Benjelloun, 2013); lack of time (Etmer, 1999); lack of confidence in the use of technology (Cox et al., 1999; Pelgrum, 2001); anxiety (Snoeyink \& Ertmer, 2001); and lack of motivation (Fabry \& Higgs, 1997; Karsenti, 2004). As McHugh (2014) puts it in his blog, 'the amount of barriers described varies, but probably the most useful summary that made was by Ertmer back in 1999, who helpfully simplified these kinds of barriers by categorizing them into two types', namely first-order barriers and second-order barriers.

In Ertmer's framework, she describes first-order barriers to technology integration as 'being extrinsic to teachers and include lack of access to computers and software, insufficient time to plan instruction, and inadequate technical and administrative support' (Ertmer, 1999: 48). Secondorder barriers, in contrast, 'are intrinsic to teachers and teaching, and include beliefs about teaching, beliefs about computers, established classroom practices, and unwillingness to change' (Ertmer, 1999: 48). Thus, first- and second-order barriers are external and internal factors, respectively, that educators have to overcome to achieve a successful integration of ICT into their teaching acts.

Besides these two barriers, Tsai and Chai (2012) propose a third-order barrier, which has to do with a lack of problem-solving capacities when using digital technologies. They refer to it 'lack of design thinking skills and disposition'. Design thinking 'seeks to change and improve current situation and create what is desired' (Tsai \& Chai, 2012:1058). According to these researchers, teachers need to rely on design thinking, as it enables them to re-orientate or create learning material and activities and to creatively repurpose tools to suit the instructional needs for different contexts.

Per Linguam 2020 36(2):90-103

http://dx.doi.org/10.5785/36-2-947 


\section{MODELS OF ICT INTEGRATION}

Integrating technologies into teaching and learning is a complex endeavour that involves many factors and presents many challenges. To address these issues and ensure a smooth integration of ICT into teaching and learning, theoretical models have been developed. They have various functions depending on their structure and descriptions. Thus, one model can serve as a framework for integration with emphasis on the different steps to follow, while another can serve as an indicator to determine the level of ICT integration process of a country or an institution. A model can also be a framework for the description of the skill set that is necessary for an effective and efficient implementation of ICT in an educational setting. Some of the prominent theoretical models conceived by researchers are the 'SAMR model' (Puentedura, 2006), 'a continuum of approaches' (UNESCO, 2004), 'Adoption, Substitution, Progrès, Innovation, Détérioration' (ASPID) (Karsenti, 2014) and 'TPACK' (Mishra \& Koehler, 2006). In this paper, I dwell on the latter because this is a framework that applies to my research site, and its adequacy needed to be studied.

\section{THE TPACK FRAMEWORK}

TPACK is an approach that is built on the assertion that teaching is an 'ill-structured' field that requires from the teacher an array of intricate types of knowledge, not only about pedagogy and content as stated by Shulman (1987), but also about technology. TPACK is a framework of reference that describes the different types of knowledge necessary for a teacher to integrate technologies into education. It is based on three core components: technology, content and pedagogy, plus the relationships between and among them, as can be seen in Figure 1 below.

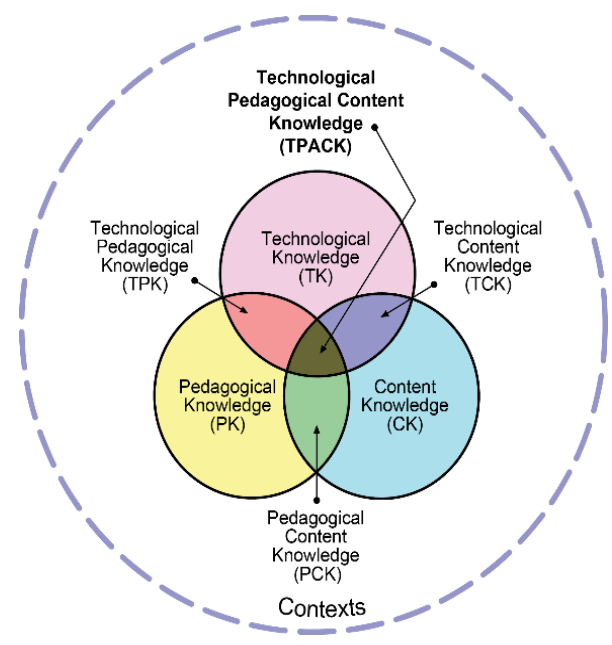

Figure1: TPACK framework and its components (Koehler, 2012)

Content knowledge (CK) has to do with what teachers know about the subject matter or the discipline. 'This knowledge would include knowledge of concepts, theories, ideas, organizational framework, knowledge of evidence and proof, as well as established practices towards developing such knowledge' (Koehler \& Mishra, 2009: 64). Pedagogical knowledge (PK) has to do with how the teachers teach. '[It] encompass[es], amongst other things, overall educational purposes, values 
and aims. This generic form of knowledge applies to understanding how students learn, general classroom management skills, lesson planning, and student assessment' (Koehler \& Mishra, 2009: 64). In other words, pedagogical knowledge is related to the mastery of teaching strategies and theories. Technological knowledge (TK) describes teachers' knowledge as far as technology is concerned. It goes beyond traditional computer literacy and requires that teachers understand ICT broadly enough to apply it productively to better impact students' learning. These three core domains of knowledge combine to create sub-domains at their intersections: TPK (technological pedagogical knowledge), PCK (pedagogical content knowledge), TCK (technological content knowledge) and TPACK (see Figure 1 above).

TPK is defined by Mishra and Koehler (2009: 65) as 'an understanding of how teaching and learning can change when particular technologies are used in particular ways. This includes knowing the pedagogical affordances and constraints of a range of technological tools as they relate to disciplinary developmentally appropriate design and strategies.' Simply put, TPK enables teachers to choose a technology that will better suit their teaching approaches, strategies and techniques. For example, which technology would be more appropriate for a teacher who adopts a socio-constructivist approach to teaching and learning and who wants his or her students to share their knowledge on a given task by collaborating?

TCK is the 'understanding of the manner in which technology and content influence and constrain one another' (Koehler \& Mishra, 2009: 65). A given technology, through its characteristics, may afford or constrain the type of knowledge to be taught. Content knowledge combined with technological knowledge enables teachers to have representations of how technology can better support or deepen disciplinary content. For example, WhatsApp may be more suitable to deliver language content than mathematical concepts as it can be used to foster students' writing skills.

$P C K$ has to do with 'knowledge of pedagogy that is applicable to the teaching of specific content' (Koehler \& Mishra, 2009: 64). PCK is the set of knowledge necessary for the content of a particular discipline. For example, for foreign language teaching, teachers need to have relevant knowledge not only about grammar, vocabulary and phonetics, but also about theories and approaches as well as methods and techniques in that field. The teachers will then be able to make informed choices for their classes and students, taking into consideration the profile of the latter.

TPACK, as can be seen in Figure 1, is at the intersection of the three major knowledge domains that constitute the model. TPACK goes beyond knowledge of technology, content and pedagogy. It emerges from interactions among these components and is the basis of effective teaching with technology (Koehler \& Mishra, 2009: 66). It is the set of skills that enables teachers to select appropriate tools and develop appropriate teaching and learning activities for their students, taking into consideration their context. 'Thus, teachers need to develop fluency and cognitive flexibility not just in each of the key domains ( $\mathrm{T}, \mathrm{P}$, and $\mathrm{C}$ ), but also in the manner in which these domains and the contextual parameters interrelate so that they can construct effectives solutions' (Koehler \& Mishra, 2009: 66). It is thought that TPACK principles were implemented during the instantiation of the CALL experience used as object of this paper and described below. 


\section{RESEARCH DESIGN AND METHODOLOGY}

The main objective of this article is to describe how some theoretical principles (barriers to CALL integration, TPACK framework) inform a particular phenomenon (CALL experience in an African context). Because this theory-testing paper seeks to test and question a framework, it is considered an explanatory research (Tremblay \& Perrier, 2006). It relies on qualitative data to achieve its goal. To collect the data that were later analysed, I carried out an experiment. This experiment was carried out in two phases during the second semester of two consecutive academic years: the pilot phase and the implementation proper. Two sets of French students who were meeting in the university information technology (IT) centre once a week voluntarily participated in the study. I signed an undertaking of mutual agreement with these students, indicating that the information provided and gathered was for the sole purpose of the research. In the course of the experiment, data were collected through a logbook in which reports were written about each session at the IT centre. The inductive analysis carried out on these data enabled me to tag them as disruptive factors to integration of CALL and break them down into categories (see Table 1 below). It is worth mentioning that this research is about my own experience. I was the teacher. Researching one's practices is an acknowledged approach. I therefore admit that the perceptions and conclusions are biased.

\section{CONTEXT OF THE RESEARCH}

The context of the study presented here is a French language class in an English-speaking university in Cameroon in central Africa. This university is one of the state universities where the language of instruction is exclusively English. ${ }^{1}$ It encourages, in line with government policy, the use of technology not only for administration, but also to enhance teaching and learning. In line with this, the authorities, through the institution's IT department, have created a platform for course registration and administration. They have often invited experts to give talks about the importance and use of ICT in education. As far as infrastructure is concerned, the university is linked to the internet through optic fibre, which makes the internet connection potentially fast. Though staff offices are not connected, they have access to the web at the IT centre where a specific space has been arranged with cable lines and Wi-Fi. In this centre, there are about 50 computers in good working state for the use of students, who can also access the internet in one of the many hotspots on the campus.

With respect to the French language course, it is a university requirement course that covers two semesters; that is, FRE 101 in the first semester and FRE 102 in the second. The objective of the course, which is entitled 'Functional French', is to provide students with linguistic tools to enable them to interact both orally and in writing in a French speaking environment. These objectives are not met because of the conditions in which the course takes place: insufficient time for class interaction (only two hours a week; 40 hours for the two semesters), heterogeneous levels of students (beginner, intermediate and advanced students can be found in the same group), the size of the class (around 80 students per class), and the fact that only listening, reading and grammar are treated in class. There is no time to work on interactional speaking or writing skills with students. In a bid to propose a solution to this problem, I chose to integrate technology into the course in what was dubbed the Melff project (Ngandeu, 2017). The project was about creating a blended learning setup whereby online activities supplemented face-to-face traditional classroom instruction. The instantiation of this setup, especially the part involving technology, is the main 
concern in this paper as I aim to show how the project was informed by the TPACK framework. However, before relating this framework to Melff project, it is important to mention, following the preceding description of the institutional context, that the first-order barriers had been removed. TPACK is associated with second-order barriers (Tsai \& Chai, 2012). The purpose of the next section is to describe how these barriers, intrinsic to the teacher, were overcome by applying the TPACK framework.

\section{TPACK AND THE INSTANTIATION OF MELFF}

For a better understanding of how TPACK knowledge applied to the experience carried out and how it contributed to remove barriers or not, it is important to give an account of how Melff was instantiated.

As mentioned in the lines above, Melff was a hybrid learning setup aimed at enabling interaction for French language learning, so the parts of the lesson that could not be done in class were done online. Of the various parts of a lesson, only access to meaning through listening or reading comprehension and systematisation of rules through exercises were done in the classroom. The production part (speaking and writing) was carried out online in the IT centre, which stood in for the language centre. The experience was carried out in two phases. The first, which was the pilot phase, involved 22 students who voluntarily opted to join the project. They were aged between 16 and 17 years. They owned no computers and mostly accessed computers as well as the internet in cybercafés or on campus. They came from different departments and had never studied online. The majority could use word processing software. The communication tool they used most was email, and when they connected to the internet, it was mostly for research purposes. The participants were put into two different groups. Each group included an expert' (student with a higher level of French). One group was to work in VoiceForum (Fynn, 2012) and the other in Moodle. Due to the fact that the groups were to meet at the IT centre (on different days), the discussions on the forums were quasi-synchronous. That is, a message posted by a member of a group could be read immediately after refreshing the page. The experience lasted 10 weeks. At the end of the pilot phase, based on difficulties that emerged, some changes were effected: online voice discussion was abandoned and some changes were made to the learning design. The second phase was carried out with the same configuration. Fifteen students effectively took part in the 10week-long experience. The students were divided into two groups who were to interact only in writing on two platforms: Moodle and Primarypad (an online collaborative writing tool). The conception and instantiation of Melff required from me the types of knowledge described by the TPACK framework.

We have seen that TPACK has to do with the types of knowledge teachers need to have for a successful integration of ICT in their classroom environment. These types of knowledge are related to the interaction between three main knowledge domains, namely technology, pedagogy and content, and the interactions between them: PCK TCK, TPK, TPACK. As the teacher in Melff, I believe I am versed with the skills involved therein.

PCK and the teacher in Melff:

PCK has to do with pedagogy as it is applied to a specific discipline. Through my training and experience $^{2}$, I have a good knowledge of the pedagogy related to teaching French as a foreign 
language. I have a good mastery of the various methodologies and learning theories applicable to French as a foreign language, as well as classroom techniques and strategies to use in order to achieve specific objectives. This knowledge informed my conception of particular tasks that would engage students in interactions in the target language.

\section{TCK and the teacher in Melff:}

TCK refers to the relationship a particular discipline has with technology. Understanding the way technology creates affordances to mediate the content of a discipline enables teachers to choose technologies that are appropriate to the content they want to deliver. Within the framework of Melff, I made the choice of a discussion forum, which is an online communication tool that provides opportunities for oral or written interaction between students. Here, it was hosted by two learning platforms: Moodle (for written interaction) and VoiceForum (for oral interaction). The choice of this technology was thought to be appropriate to the pedagogical design and strategies put in place to enable writing and speaking skills in a French as a foreign language class.

TPK and the teacher in Melff:

With TPK, teachers are able to choose an appropriate technology based on their teaching philosophy. In addition, they will be able to determine from the affordances of a given technology the use that best suits their teaching methods, techniques and strategies. I believe that students learn better by interacting either with the teacher or with their peers. In the course of the interaction in the target language, they have inputs and outputs; they receive feedback, reformulate erroneous outputs and learn. This socio-constructivist view of learning made me choose a technological tool (discussion forum) that would facilitate the implementation of learnercentred and interaction-rich tasks.

TPACK and the teacher in Melff:

So far, we have seen that I am well versed in the types of knowledge resulting from the combination between any two of the three main knowledge domains that make up the TPACK framework. At the heart of this framework is the set of skills involving all three domains. Integrating knowledge of technology, pedagogy and content in specific context, according to Koehler and Mishra (2009), is the way to achieve successful integration of ICT. I believe that TPACK was part of my stock of knowledge in Melff. It informed the choice of technology in accordance with the foreign language pedagogy and content. Thanks to that knowledge, the discussion forum as a communication tool on the Moodle platform could be repurposed during the conception phase. An asynchronous tool was used as a synchronous tool in a quasi-synchronous discussion in order to cope with one of the obstacles from the context, namely that, because of a lack of personal computers, students had to gather at the language centre to carry on the interaction task assigned to them. Still relying on the information gathered from the context concerning the quality of the infrastructure, the choice of technology was made in such a way that it matched my active pedagogy approach.

In this part of the paper, I have described the Melff project in its instantiation in order to provide better insight into the next section. I have also shown how the TPACK framework related to a case of ICT integration in a language course. It was precisely stated that I, as the teacher in the 
said case, possessed a mastery of technology, pedagogy and content, as well as interactions between them, a body of knowledge that was supposed to enable me to overcome second-order barriers (Tsai \& Chai, 2012) in an environment where first-order barriers were thought to be quasi-inexistent. Yet, during the implementation of this CALL project, a number of disruptive factors emerged. An analysis of these factors is presented hereafter.

\section{MELFF AND EMERGING DISRUPTIVE FACTORS}

During the implementation of the CALL project, despite my stock of knowledge, a number of obstacles were noted to the smooth integration of ICT into the French language course at this university. During the two phases of the project (pilot and implementation phases), a logbook was kept in which all the occurrences during the sessions in the IT centre were carefully noted. The data gathered enabled me to tag the disruptive factors according to the scope of their consequences: meaningless disruption, light disruption, serious disruption, very serious disruption and disruption having caused the cancellation of a session. Below is a tabular visual representation of these disruptions. The legend is as follows:

\begin{tabular}{|c|c|c|c|c|}
\hline $\begin{array}{l}\text { Meaningless } \\
\text { disruption }\end{array}$ & $\begin{array}{c}\text { Light } \\
\text { disruption }\end{array}$ & $\begin{array}{c}\text { Serious } \\
\text { disruption }\end{array}$ & $\begin{array}{l}\text { Very serious } \\
\text { disruption }\end{array}$ & $\begin{array}{l}\text { Disruption having caused } \\
\text { the cancellation of a } \\
\text { session }\end{array}$ \\
\hline
\end{tabular}

Table 1: Visual representation of the disruptions noted during the instantiation of Melff

\begin{tabular}{|c|c|c|c|c|c|c|c|c|c|c|c|}
\hline \multirow{2}{*}{$\begin{array}{c}\text { Melff - pilot } \\
\text { Disruptions }\end{array}$} & \multicolumn{8}{|c|}{ Group AR } \\
\hline
\end{tabular}

\begin{tabular}{|c|c|c|c|c|c|c|c|c|c|c|c|c|c|c|c|c|c|c|c|c|c|c|}
\hline \multirow{3}{*}{$\begin{array}{c}\text { Melff - phase } 2 \\
\text { Disruptions } \\
\end{array}$} & \multicolumn{11}{|c|}{ Group AL } & \multicolumn{11}{|c|}{ Group Y } \\
\hline & \multicolumn{11}{|c|}{ Sessions } & \multicolumn{11}{|c|}{ Sessions } \\
\hline & S1 & S2 & S3 & 54 & 55 & $\mathrm{S6}$ & S7 & 58 & 59 & $\mathrm{~S} 10$ & S11 & S1 & $\mathrm{S2}$ & S3 & 54 & 55 & 56 & 57 & 58 & 59 & $\mathrm{~S} 10$ & S11 \\
\hline Computer skills & & & & & & & & & & & & & & & & & & & & & & \\
\hline Internet & & & & & & & & & & & & & & & & & & & & & & \\
\hline Computers & & & & & & & & & & & & & & & & & & & & & & \\
\hline Power cut & & & & & & & & & & & & & & & & & & & & & & \\
\hline Strikes & & & & & & & & & & & & & & & & & & & & & & \\
\hline Public holidays & & & & & & & & & & & & & & & & & & & & & & \\
\hline University games & & & & & & & & & & & & & & & & & & & & & & \\
\hline Absences & & & & & & & & & & & & 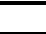 & & & & & & & & & & \\
\hline Lateness & & & & & & & & & & & & & & & & & & & & & & \\
\hline RECAP & & & & & & & & & & & & & & & & & & & & & & \\
\hline
\end{tabular}

As Table 1 shows, the integration of ICT in a French language course encountered some difficulties that disrupted the process to a lesser or greater extent. These disruptions were related 
either to the institution (internet, strikes, computers, power cuts, public holidays, university games) or the actors (computer skills, absences, lateness).

The internet constituted a serious obstacle at the beginning of the project, to the extent that the oral interaction was cancelled. The instability of the internet connection disrupted the sessions and led to the cancelation of four lessons. It is important to note that, though the IT centre is connected to the internet thought optic fibre, the bandwidth was not sufficient to supply the computers of the institution at peak connection hours. Computer skills as an obstacle had to do with the fact that some participants could not manage many browser tabs and had inoperative email addresses. Computers were configured in such a way that users could not install programs on them. Software that was allowed was automatically uninstalled after one day. That is one reason why interaction on VoiceForum and Primarypad was abandoned. There were power cuts during some sessions, and the computers had no backup energy. At times, the power cuts lasted for so long that the session had to be cancelled. Public holidays, as well as the period during which the university games take place, cause the IT centre to be closed. Absences of either the participants, myself or IT technicians seriously disrupted the experience, and would either cause the session not to be effective or lead to its cancellation.

The conclusion that can be drawn when glancing at the tables above is that the project of integrating ICT into a language course was considerably disrupted. The last row of each table recapitulates the disruptions recorded in each session, with the most serious being considered at the end of a column. It can be seen that most sessions did not hold, especially for the first group in phase 2. The occurrence of these disruptive factors calls for a number of questions. Based on the fact that ICT is beneficial to language teaching and learning, a model of integration that has proven to be efficient was chosen, namely blended learning built around the language centre. We have seen that the institution provides basic conditions and necessary infrastructures for CALL integration (Martins \& Moreira, 2017). I, the teacher in the project described here, have a good blend of technology, pedagogy and content knowledge. Yet, there were still barriers. The questions we may ask are: Is the type of hybrid mode chosen not appropriate for a low-tech context? Is the TPACK model sufficient? Are additional skills required from the teacher?

\section{DISCUSSION}

The use of technology in teaching and learning in general, and in language teaching and learning in particular, is on the rise (Wu, 2013). Effective integration of ICT requires a set of skills, and researchers have been proposing frameworks in order to conceptualise this skill set. The TPACK framework appears to be the most coherent and practicable framework (Tai, 2013). It has been used to describe the knowledge base that teachers of English as foreign language will need to effectively teach with technology (Debbagh \& Jones, 2015). According to Keengwe and Kang (2012), the combination of the three knowledge domains, namely content, pedagogy and technology, is required for a successful application of TPACK in English language teaching: (1) content components in the curriculum - language skills and culture; (2) pedagogical components in second language teaching - the communicative approach and the task-based learning approach; and (3) technological components - choosing appropriate technological tools.

I have been able, in the framework of a CALL project, to put together my knowledge of subject matter (French as foreign language with its theories and approaches) and the appropriate 
pedagogy (task-based activities, group work with respect to the objectives) to choose suitable technologies (discussion forums) in order to enhance teaching and learning. Yet, the project cannot be said to be successful if one goes by the obstacles or barriers that emerged. That is why this paper questions the TPACK framework by asking if it is sufficient for the successful integration of ICT into language teaching and learning or into education in general. My position is that a successful integration requires more than just TPACK knowledge. I agree with Tsai and Chai (2012) when they say that 'barriers will always exist in one way or another', and because the classroom context and students are quite dynamic, the teacher should rely on some skills that go beyond the TPACK knowledge, called 'design thinking'. Design thinking enables teachers to overcome contextual challenges by creatively reorganising and adapting learning material and activities to instructional needs (Tsai \& Chai, 2012: 1058). According to Tsai and Chai (2012), design thinking tackles both first- and second-order barriers as it considers all barriers as obstacles that need to be overcome through creative thinking. They add that this creative thinking capacity is sharpened in technology-poor environments. I agree totally with this view and believe that, if I succeeded in obtaining interactive messages, through which learning is considered to have taken place according to interactionist theory (Ngandeu, 2017: 197), it is thanks to the design thinking ability. I was able to reorganise activities and leaning material in order to cope with structural and circumstantial challenges. For example, some activities that were normally carried out individually were done in groups, that is, with two or three students in front of a single computer; arrangements were made for students to access the language centre out of the scheduled time; and make-up sessions were organised for cancelled regular sessions at the language centre. Design thinking capacities are necessary in low-tech contexts because the question in the 21 st century is no longer when to integrate ICT in education, but how to do it.

Besides this design thinking, I also believe that teachers who want to integrate technology in their course must have some knowledge of managing innovation. Once ICT is introduced in a course, it brings about change that affects the method or way of teaching certain disciplinary content. Innovation is a complex and dynamic process that is spread over time (Peraya et al., 2004). Therefore, teachers should be able to pilot this innovation. This involves the capacity to gather information during implementation, analyse it, draw conclusions and reinvest them to the process until a state of relative stability is reached. Such capacities enabled me to realise that the language centre-based blended learning I adopted was not the best for my context. Mobile learning is then envisaged for the continuation of the project. According to a report by We Are Social and Hootsuite (2020), two institutions that specialise in controlling traffic on social media and the internet, mobile phones were the most used devices to access the internet in 2019 in Cameroon (59.4\% of web traffic against $36.4 \%$ from laptops and desktops). According to this same report, the quality of internet is good $(16.85 \mathrm{Mbps})$. With these facts, it is clear that a setup built around mobile learning will be better in my context than one built around fixed technology. As Gonzales and St. Louis (2013: 219) put it, 'learning in low-tech contexts is feasible and although poor Internet access can be an obstacle, it is one that can be overcome ... mobile phones are examples of mediums trough which language can be accessed in low-technology contexts.' My hypothesis, in envisaging mobile-assisted language learning (MALL) as a follow up to Melff is that, with MALL, students will not have to depend on a particular location or person to access the content of their training. They can conveniently work from wherever they are without fear of power cuts. With the mobile version of Moodle, they can work offline and need the internet only to synchronise with the server. During strikes, public holidays or university games, students can 
access the content via their mobile phones and carry on the tasks assigned to them. As they will not need to walk to the language centre, the issue of lateness and absences will not be present. To sum it up, mobile technologies would have prevented the types of interruption described above.

\section{CONCLUSION}

This paper questions the sufficiency of the TPACK framework for the successful integration of ICT in an African low-tech context. To this effect, and as an explanatory research paper, it set out to test some theoretical frameworks as they apply to a situation. It started by presenting the various barriers that could impede technology integration through Ertmer's (1999) categorisation of first- and second-order barriers, which are external and internal to the teacher, respectively. Also presented is a third-order barrier, which is the lack of 'design thinking' and has to do with the problem-solving capacities. The paper further described the TPACK framework, a knowledge system required for successful integration of IT, and related it to a CALL experience in an African context. This experience was carried out in an environment where the basic conditions and infrastructure for technology integration were provided. I, as teacher and main actor in this experience, possess the knowledge described by the TPACK framework. Yet, during the instantiation of the CALL project, a number of disturbing factors emerged. This paper then concluded that more than TPACK knowledge is needed to deal with barriers to technology integration. It therefore proposed design thinking and knowledge about how to pilot innovation as additional skills required from any teachers who intend to enhance their teaching with technology in a 'resource constrained context'(Tulinayo et al., 2018). As theory-testing research, this research was limited to a case study, and its findings may be generalised only after replication in other situations. Therefore, further research may consist of testing the TPACK framework in other low-tech contexts in sub-Saharan Africa.

\section{END NOTES}

\footnotetext{
${ }^{1}$ There are eight State universities in Cameroon. The two which are situated in the English-speaking part of the of the country have English as language of instruction, while in the other six, teachers can use either English or French to teach, and students can use either language to answer questions, except in one where the language of instruction is French.

2 I hold a master's degree in the teaching of French as a foreign language, a master's in the use of ICT in teaching and learning, and have more than 15 years' teaching experience.
}

\section{REFERENCES}

ANGELI, C., \& VALANIDES, N. 2005. Preservice teachers as ICT designers: An instructional design model based on an expanded view of pedagogical content knowledge. Journal of Computer-Assisted Learning, 21(4), 292-302

COEN, P. F. SCHUMACHER, J. 2006. Construction d'un outil pour évaluer le degré d'intégration des TIC dans l'enseignement. Revue internationale des technologies en pédagogie universitaire , 3(3), 7-17.

COX, M. J., COX, K., \& Preston, C. 2000. What factors support or prevent teachers from using ICT in their classrooms? paper presented at the British Educational Research Association Annual Conference, Brighton, 2-5 September. Available at: http://www.leeds.ac.uk/educol/documents/00001304.htm 
CUBAN, L. (2001). Oversold and underused: Computers in the classroom. Harvard University Press.

DEBBAGH, M. \& JONES, W.M. 2015. Using the TPACK Framework to Examine Technology Integration in English Language Teaching. In D. Rutledge \& D. Slykhuis (Eds.), Proceedings of SITE 2015--Society for Information Technology \& Teacher Education International Conference (pp. 3121-3126). Las Vegas, NV. Available at: https://www.learntechlib.org/primary/p/150436/.

ERTMER, P. A. 1999. Addressing first- and second-order barriers to change: Strategies for technology integration. Educational Technology Research and Development, 47(4), p. 4761.

FABRY, D. L., \& HIGGS, J. R. 1997. Barriers to the effective use of technology in education: Current status. Journal of Educational Computing Research, 17(4), 385-395.

FYNN, J. 2007. Aide à l'apprentissage du discours oral dans un contexte de communication asynchrone, Apprentissage des Langues et Systèmes d'Information et de Communication (ALSIC) 10(1). DOI : 10.4000/alsic.586

GONZALEZ, D., \& ST. LOUIS, R. 2013. CALL in low-tech contexts. In Contemporary Computer-Assisted Language Learning (Bloomsbury, pp. 217-241). London, UK \& New york, US.

KARSENTI, T. 2004. The impact of attitudes and technological abilities of future teachers' use of information and communication technology (ICT) with school children. In Proceedings of the 4th Hellenic conference on Information and communication technologies in education (Vol. A, p. 63-72). Athens, Greece : New Technologies Publications.

KARSENTI, T. 2014. Modèle ASPID du processus d'intégration des technologies en éducation. Available at: http://karsenti.ca/aspid/

KEENGWE, J., \& KANG, J.J. 2012. Preparing in-service language teachers to design and implement technology-rich curriculum. Education and Information Technologies, 18, (4), 609-619.

KOEHLER, M. 2012. The seven component of TPACK. Available at http://mattkoehler.com/tpack2/tpack-explained/ [accessed: 15 May 2019]

KOEHLER, M. \& MISHRA, P. 2009. What is technological pedagogical content knowledge (TPACK)? Contemporary Issues in Technology and Teacher Education, 9 (1) (2009), pp. 60-70

LWOGA, E. 2012. Making learning and Web 2.0 technologies work for higher learning institutions in Africa.CWIS,29(2), 90-107

MARTINS, C. B. \& MOREIRA, L. 2017 CALL integration into Modern Languages Courses in Brazil: teachers' views on the role of context. In J. Colpaert, A. Aerts, R. Kern, M. Kaiser (Eds), CALL in Context. Paper presented at the CALL conferences, University of California, Berkeley, 7 - 9 July (pp. 5040-510), Antwerp: Universiteit Antwerpe

MCHUGH, S. 2014, October 4. The 3rd Barier to Tech Integration [Blog post]. Available at: http://prOtean.blogspot.com/2014/07/interthinking-interaction-internet.html

MISHRA, P., \& KOEHLER, M. J. 2006. Technological Pedagogical Content Knowledge: A new framework for teacher knowledge. Teachers College Record 108 (6), 1017-1054.

NGANDEU, B. 2017 : Projet MELFF ou la mise en œuvre d'un dispositif hybride pour l'amélioration du cours de français langue étrangère à l'université de Buea, African Journal of Special Education, vol 2 (4). pp. 192-205 
OMAR, A. \& BENJELLOUN, N. 2013. Intégration des TIC dans l'enseignement des sciences physiques au Maroc dans le cadredu programme GENIE : difficultés et obstacles. Revue internationale des technologies en pédagogie universitaire, 10(2), 49-65. Available at: https://doi.org/10.7202/1035522ar

PELGRUM, W. J. (2001). Obstacles to the integration of ICT in education: Results from a worldwide educational assessment. Computers and Education, 37, 163-178.

PERAYA, D. ET B. JACCAZ (2004). Analyser, Soutenir, et Piloter l'innovation : un modèle " ASPI ". Colloque TICE 2004, Technologies de l'information et de la connaissance dans l'enseignement supérieur et l'industrie. Université de technologie, Compiègne (19 au 21 octobre

POELLHUBER, B. \& BOULANGER, R. 2001. Un modèle constructiviste d'intégration des TIC : rapport de recherche. Available at: http://ntic.org/docs/constructiviste.pdf

PUENTEDURA, R.. 2006, November 28. Transformation, technology, and education in the state of Maine [Web log post]. Available at: http://www.hippasus.com/rrpweblog/archives/2006_11.htm

RUMANYIKA, J.D., \& Galan, R.M. 2015.Challenges for teaching and learning in formation and communication technology courses in higher learning institutions in Tanzania: A review. Information and Knowledge Management, 5(2), 1-12.

SNOEYINK, R., \& ERTMER, P. A. 2002. Thrust into technology: how veteran teachers respond.

SSEKAKUBO, G., SULEMAN,H., \& MARSDEN, G. 2011. Proceedings of the south African institute of computer scientists and information technologists conference on knowledge, innovation and leadership in a diverse, multidisciplinary environment, (pp.231-238). Cape Town: ACM. Available at: http://pubs.cs.uct.ac.za/archive/00000712/01/p231ssekakubo.pdf.

TAI, SHU-JU DIANA, "From TPACK-in-Action Workshops to English Classrooms: CALL Competencies Developed and Adopted into Classroom Teaching" (2013). Graduate Theses and Dissertations. 13335. Available at: https://lib.dr.iastate.edu/etd/13335

TREMBLAY, R. R. \&. PERRIER, Y. 2006. Savoir plus : outils et méthodes de travail intellectuel, Montréal, Chenelière/McGraw-Hill, $230 \mathrm{p}$

TSAI, C.-C. \& CHAI, C. S. 2012. The "third"-order barrier for technology integration instruction: Implications for teacher education. Building the ICT capacity of the next generation of teachers in Asia. Australasian Journal of Educational Technology, 28(6), 1057-1060.

TULINAYO, F., SSENTUME, P., NAJJUMA, R. 2018. Digital technologies in resource constrained higher institutions of learning: a study on students' acceptance and usability. International Journal of Educational Technology in Higher Education. Available at: https://doi.org/10.1186/s41239-018-0117-y

UNESCO 2002. ICT in Education - a curriculum for schools and programme of teacher development. Available at: http://unesdoc.unesco.org/images/0012/001295/129538e.pdf

WE ARE SOCIAL \& HOOTSUITE, 2020. Digital 2020: Digital Global Overview. Available at https://datareportal.com/reports/digital-2020-global-digital-overview

WU, Y.T. 2013. Research trends in technological pedagogical content knowledge (TPACK) research: A review of empirical studies published in selected journals from 2002 to 2011. British Journal of Educational Technology, 44, (3), 73-76 


\section{BIOGRAPHICAL NOTE}

Dr Ngandeu holds a Master in the Teaching of French as a Foreign Language, a Master in the Use of ICTs in Teaching and Learning and a PhD in language sciences. he is a senior lecturer at the University of Buea-Cameroon, and at the time he wrote this article he was a research fellow at the University of Kwazulu-Natal. His research interests include CALL and MALL in technologically challenged environments 